\title{
Deadlocked in Dualism: Negotiating for a Final Settlement
}

\author{
Andreas von Arnauld
}

\begin{abstract}
While on the international plane Germany has as strong a position as one could wish for, a second appeal to the ICJ does not seem advisable. Though not formally estopped from challenging Sentenza 238/2014, Germany would at least face a principled contradiction (Wertungswiderspruch). Like Italy, Germany takes the position that international obligations must be disregarded should they be found incompatible with fundamental rights enshrined in the national constitution. Concerning the underlying conflict, another formally strong German position proves to have inherent shortcomings. To argue that, as far as Italian citizens are concerned, all matters of compensation had been dealt with comprehensively in the GermanItalian lump sum agreement of 1961 carries some conviction. However, the limitations of that agreement, the erosion of the individual's strict mediatisation in international law, and recent German compensation schemes for other victims of World War II (WWII) have fuelled a growing discontent with this final settlement. Having been doubly denied recognition as victims by the injustices of non-retroactivity and of differentiation, the Italian WWII victims 'in oblivion' have pursued compensation claims for over a decade now. It would go too far to argue an individual claim for financial compensation under international law for historic wrongs. The principle of intertemporal law, however, has its merits as well as its defects. This chapter argues in favour of mildly piercing the veil of intertemporality by reliance on fundamental ethical principles as part of the law in force already at the time of the original violation. A breach in this kind of obligation should give rise to an obligatio de negotiando under the principle of just satisfaction. Such a legal construction takes up the idea that in most of the recent cases of 'history taken to court', compensation is but a secondary aim, the primary aim being to 'tell one's own story' as a counter-narrative to hegemonic discourse. By entering into negotiations with the victims 'in oblivion', Germany-and Italy-could and should attempt to finally solve what has been and remains a fundamentally unjust situation.
\end{abstract}

\footnotetext{
A. von Arnauld $(\bowtie)$

University of Kiel, Walther Schücking Institute for International Law, Kiel, Germany

e-mail: arnauld@wsi.uni-kiel.de

(C) The Author(s) 2021

V. Volpe et al. (eds.), Remedies against Immunity?, Beiträge zum ausländischen öffentlichen Recht und Völkerrecht 297, https://doi.org/10.1007/978-3-662-62304-6_16
} 


\section{Jurisdictional Immunities, or a Formally Strong German Position}

On the international plane, Germany has as strong a position as one could wish for. In its 2012 Jurisdictional Immunities Judgment, the International Court of Justice (ICJ) in unambiguous terms found Italy responsible for a threefold violation of the customary principles of state immunity vis-à-vis the Federal Republic of Germany: by allowing civil claims against Germany in the first place; by taking measures of constraint against Villa Vigoni, which serves a non-commercial government purpose; and by declaring enforceable in Italy decisions of Greek courts upholding civil claims against Germany. ${ }^{1}$ Nevertheless, in two of the judgment's 139 paragraphs the ICJ voiced 'surprise' and 'regret' that 'Germany decided to deny compensation' to the great majority of Italian World War II (WWII) Military Internees (IMIs) and pointed out that claims arising from their treatment 'could be the subject of further negotiation involving the two States concerned, with a view to resolving the issue'. Legally speaking, however, the position taken by the Court was so clear that several commentators saw a missed opportunity for allowing future developments of the law of state immunity in cases of grave breaches of human rights. ${ }^{3}$

The ICJ did not stop here. By fourteen votes to one it found that 'the Italian Republic must, by enacting appropriate legislation, or by resorting to other methods of its choosing, ensure that the decisions of its courts and those of other judicial authorities infringing the immunity which the Federal Republic of Germany enjoys under international law cease to have effect'. ${ }^{4}$ Neither under the ICJ Statute nor under general international law can Italy invoke provisions of its internal law as justification for its failure to conform with the judgment. This would run counter to

\footnotetext{
${ }^{1}$ ICJ, Jurisdictional Immunities of the State (Germany v Italy: Greece intervening), Judgment of 3 February 2012, ICJ Reports 2012, 99, para 139.

${ }^{2}$ Ibid, paras 99; 104.

${ }^{3}$ See, eg, Carlos Esposito, 'Jus Cogens and Jurisdictional Immunities of States at the International Court of Justice: "A Conflict Does Exist”, Italian Yearbook of International Law 21 (2011), 161-174; Marco Calisto, 'Jurisdictional Immunities of the State: Germany v Italy before the ICJ from an Italian Perspective', German Yearbook of International Law 55 (2012), 319-343; Francesco Francioni, 'From Utopia to Disenchantment: The Ill Fate of "Moderate Monism" in the ICJ Judgment on the Jurisdictional Immunities of the State', European Journal of International Law 23 (2012), 1125-1132; Sangeeta Shah, 'Jurisdictional Immunities of the State: Germany v Italy', Human Rights Law Review 12 (2012), 555-573; Kimberley Trapp/Alex Mills, 'Smooth Runs the Water where the Brook is Deep: The Obscured Complexities of Germany v Italy', Cambridge Journal of International and Comparative Law 1 (2012), 153-168; Michael Bothe, 'Remedies of Victims of War Crimes and Crimes against Humanities: Some Critical Remarks on the ICJ's Judgment on the Jurisdictional Immunity of States', in Anne Peters/Evelyne Lagrange/Stefan Oeter/Christian Tomuschat (eds), Immunities in the Age of Global Constitutionalism (Leiden: Brill 2015), 99-115. In a similar vein, Markus Krajewski/Christopher Singer, 'Should Judges be Front-Runners? The ICJ, State Immunity and the Protection of Fundamental Human Rights', Max Planck Yearbook of United Nations Law 16 (2012), 1-34.
}

${ }^{4}$ ICJ, Jurisdictional Immunities (n 1), para 139, sub 4. 
the customary rule codified in Article 27 of the Vienna Convention of the Law of Treaties, according to which a state 'may not invoke the provisions of its internal law as justification for its failure to perform a treaty'. Some scholarly creativity notwithstanding, there can be little doubt that Sentenza 238/2014 is in clear contradiction to Italy's obligations under the ICJ Statute, thus adding to the violation of the principle of state immunity itself. ${ }^{5}$

Theoretically, Germany could therefore appeal a second time to the ICJ in order to challenge the 2014 judgment by the Corte Costituzionale. ${ }^{6}$ While the ICJ in 2012 expressly rejected Germany's claim for a guarantee of non-repetition, as it saw no indication that Italy would not comply with the judgment, ${ }^{7}$ the Court could probably be less reluctant this time. Germany might even ask the ICJ for an 'equitable satisfaction'. Though unprecedented, it seems at least arguable that the Italian Constitutional Court's express order not to respect the 2012 judgment corresponds to the situation provided for in Article 30 of the European Convention on Dispute Settlement, namely that one party's municipal law does not fully permit the execution of an ICJ judgment. A point of conjecture is how the ICJ would assess the fact that there is less a dispute between the German and Italian governments than between both respective governments and the Italian judiciary. ${ }^{8}$ However, as long

\footnotetext{
${ }^{5}$ Filippo Fontanelli, 'I know it's wrong but I just can't do right: First impressions on judgment no. 238 of 2014 of the Italian Constitutional Court', VerfBlog, (27 October 2014), available at https://verfassungsblog.de/know-wrong-just-cant-right-first-impressions-judgment-238-2014-ital ian-constitutional-court/; Robert Kolb, 'The Relationship between the International and the Municipal Legal Order: Reflections on the Decision no 238/2014 of the Italian Constitutional Court', Questions of International Law: Zoom Out 2 (2014), 5-16; Anne Peters, 'Let Not Triepel Triumph-How To Make the Best Out of Sentenza No. 238 of the Italian Constitutional Court for a Global Legal Order', EJIL Talk!, (22 December 2014), available at www.ejiltalk.org/let-not-triepeltriumph-how-to-make-the-best-out-of-sentenza-no-238-of-the-italian-constitutional-court-for-aglobal-legal-order-part-i/; Karin Oellers-Frahm, 'Das italienische Verfassungsgericht und das Völkerrecht-eine unerfreuliche Beziehung', Europäische Grundrechte-Zeitschrift 42 (2015), 8-16. A more positive assessment 'as a contribution to a dialectic and normative learning process between a revolutionary and emancipatory Kantian constitutional mindset and a conservative and evolutionary managerial mindset' is offered by Felix Würkert, 'Historische Immunität?', Archiv des Völkerrechts 53 (2015), 90-120. Positive reception also by Riccardo Pisillo Mazzeschi, 'Access to Justice in Constitutional and International Law: The Recent Judgment of the Italian Constitutional Court', Italian Yearbook of International Law 24 (2015), 9-23, stressing the need to strengthen the international (!) human right of access to justice. Concurring, Gianluigi Palombella, 'German War Crimes and the Rule of International Law', Journal of International Criminal Justice 14 (2016), 607-613.

${ }^{6}$ Arguably, it is not the judgment in itself, but only its application by the Italian judiciary which constitutes a direct violation of international legal obligations: Massimo Iovane, 'The Italian Constitutional Court Judgment No. 238 and the Myth of the "Constitutionalization" of International Law', Journal of International Criminal Justice 14 (2016), 595-605.

${ }^{7}$ ICJ, Jurisdictional Immunities (n 1), para 138.

${ }^{8}$ Karin Oellers-Frahm, 'A Never-Ending Story: The International Court of Justice-The Italian Constitutional Court-Italian Tribunals and the Question of Immunity', Heidelberg Journal of International Law 76 (2016), 193-202; see also Paolo Palchetti, chapter 'Right of Access to (Italian) Courts über alles?', in this volume. Cf, in general, Ingrid Wuerth, 'International Law in Domestic
} 
as Germany's immunity from enforcement measures is still respected by Italian authorities, the lack of clear damage requiring 'equitable satisfaction' might turn this into a moot point altogether.

\section{Trapped in Contradictions, or the Ambivalence of Dualism}

Even if Germany could successfully claim satisfaction before the ICJ, and even if it were to distribute said satisfaction to the victims of German WWII atrocities as a sign that it does not oppose compensation as such, the question remains whether such a move seems at all advisable. Because of its own dualist stance towards international law, Germany is trapped in what one might call the 'ambivalence of dualism'.

The Corte Costituzionale based its act of disobedience on basic tenets of the Italian Constitution (the so-called dottrina dei controlimiti), especially its guarantee of human rights and access to justice. ${ }^{9}$ Both, however, are also foundational elements of the German constitutional order-protected by Article 79(3) of the Basic Law even against constitutional amendments. ${ }^{10}$ This has, in fact, been the legal basis for the Federal Constitutional Court's (FCC) Solange saga: since Germany could never transfer public authority to the EU in a manner violating the Constitution's core 'identity', the Bundesverfassungsgericht remains competent, in principle, to control Acts emanating from the EU on their compatibility with fundamental rights guarantees. ${ }^{11}$ That this might result in disregarding obligations from EU law is part and parcel.

While this conflict might have appeared solved since the Solange II armistice between the FCC and the European Court of Justice (ECJ), ${ }^{12}$ recent decisions clearly

Courts and the Jurisdictional Immunities of the State Case', Melbourne Journal of International Law 13 (2012), 819-837, at 829-835. Paolo Palchetti argues that the Constitutional Court should have deferred the matter to the political organs on the basis of an emerging international and constitutional obligation to exercise diplomatic protection, 'Can State Action on Behalf of Victims Be an Alternative to Individual Access to Justice in Case of Grave Breaches of Human Rights?', Italian Yearbook of International Law 24 (2015), 53-60. Taking a similar line, Enzo Cannizzaro, 'Jurisdictional Immunities and Judicial Protection: The Decision of the Italian Constitutional Court No. 238 of 2014', Rivista di diritto internazionale 98 (2015), 126-134, at 130-131; Francesco Francioni, 'Access to Justice and Its Pitfalls: Reparation for War Crimes and the Italian Constitutional Court', Journal of International Criminal Justice 14 (2016), 629-636.

${ }^{9}$ Corte Costituzionale, Judgment of 22 October 2014, No 238/2014, para 3.5.

${ }^{10}$ That the relevant provisions of the Italian Constitution also 'fall outside the scope of constitutional review' has been stated by the Corte Costituzionale, as well, (n 9), para 3.2.

${ }^{11}$ Bundesverfassungsgericht, Decision of 29 May 1974, 2 BvL 52/71, BVerfGE 37, 271 (Solange I).

${ }^{12}$ Bundesverfassungsgericht, Decision of 22 October 1986, 2 BvR 197/83, BVerfGE 73, 339 (Solange II). 
show that the Bundesverfassungsgericht is still prepared to disobey international and supranational obligations on the basis of internal constitutional principles. On 15 December 2015 the Court infamously accepted an unconditional 'treaty override' by the German Parliament, based on an 'absolute' interpretation of the democratic principle (an exception was made, however, for human rights treaties) ${ }^{13}$ even more pertinent is a decision, from the very same day, concerning the execution of a European arrest warrant. ${ }^{14}$ Here, the FCC amended its Solange jurisprudence. It argued a competence and even a duty of German courts to assess whether the accused will be inhumanely treated in the member state demanding extradition, according to the standard of Article 1(1) of the Basic Law. Should such treatment be reasonably expected, the extradition is not to be granted. As the case at hand concerned convictions in absentia, the FCC stressed that fundamental principles of due process directly derive from human dignity and could thus trump any supranational obligation to extradite. It makes no real difference that the FCC superficially avoided the conflict with the ECJ by stating that a correct application of EU law would lead to the same conclusion: $:^{15}$ the 'correct' application of EU law being in open contradiction to the ECJ's—admittedly flawed-Melloni judgment of $2013 .{ }^{16}$

Since the aforementioned case and that of Sentenza 238/2014 are unrelated, ${ }^{17}$ Germany would not be formally estopped from challenging before the ICJ a legal position it takes itself within the context of EU obligations; Germany would, however, be at least trapped in a principled contradiction (Wertungswiderspruch) should it attack on the international plane Sentenza 238/2014 as disregarding the

\footnotetext{
${ }^{13}$ Bundesverfassungsgericht, Decision of 15 December 2015, 2 BvL 1/12, BVerfGE 141, 1 (Treaty Override).

${ }^{14}$ Bundesverfassungsgericht, Decision of 15 December 2015, 2 BvR 2735/14, BVerfGE 140, 317 (European Arrest Warrant II/Identity Control).

${ }^{15}$ FCC, European Arrest Warrant II (n 14), 355-366. On a rhetorical level, however, the German court's approach might at least be seen as inviting judicial dialogue-what the Italian court's Sentenza did not; cf Kolb, 'The international and the municipal legal order' (2014) (n 5), at 6 ('a high peak of a new form of robust dualism'). Also critical towards Sentenza 238/2014 for this reason, Raffaela Kunz, 'The Italian Constitutional Court and "Constructive Contestation": A Miscarried Attempt?', Journal of International Criminal Justice 14 (2016), 621-627; see also, Raffaela Kunz, chapter 'Teaching the World Court Makes a Bad Case', in this volume. The ECJ has, in fact, taken up the 'invitation' in its judgment of 5 April 2016, C-404/15 and C-659/15 PPU (Aranyosi and Căldăraru), ECLI:EU:C:2016:198.

${ }^{16}$ ECJ, Melloni, Judgment of 26 February 2013, C-399/11, ECLI:EU:C:2013:107. As to the incompatibility of both decisions see, eg, Christopher Bilz, 'Konfrontation statt Kooperation? "Solange III" und die Melloni-Entscheidung des EuGH', Juwiss Blog, (15 March 2016), available at www.juwiss.de/26-2016/.

${ }^{17}$ It might be interesting to note that Nazi criminals who were convicted for civilian massacres in Italy during WWII were generally tried in absentia. Germany over the years constantly refused extradition or to execute these judgments in Germany. See Antonio Sabino, 'Anno Giudiziario 2018: Intervento del Procuratore Generale Militare della Repubblica presso la Corte Militare di Appello' (1 March 2018), available at https://www.difesa.it/Giustizia_Militare/rassegna/ Bimestrale/2018/Documents/2_2018/3\%20Relazione\%20dott.\%20SABINO\%20PGMCMA.pdf, $1-44$, at $43-44$.
} 
ICJ's judgment. ${ }^{18}$ Like Italy, Germany takes the position that international-and even supranational ${ }^{19}$ —obligations must be disregarded should they collide with basic constitutional principles of domestic law; like Italy, Germany takes the position that due process is one of the grounds that justifies this kind of disobedience. To make this contradiction even more palpable: the European arrest warrant under German scrutiny had been issued-ironically-by Italy. ${ }^{20}$

\section{Germany and the Law \& Politics of History}

Germany is trapped in yet another contradiction: while German foreign policy has traditionally favoured a mildly progressive path in international law, laying special emphasis on the importance of human rights, ${ }^{21}$ the Distomo and Ferrini cases forced Germany into the role of an advocate of old-school interstate law. ${ }^{22}$ For obvious

\footnotetext{
${ }^{18}$ Concurring with Giuseppe Cataldi, 'A Historic Decision of the Italian Constitutional Court on the Balance between the Italian Legal Order's Fundamental Values and Customary International Law', Italian Yearbook of International Law 24 (2015), 37-52. Similarities in both courts' approaches (and that of the ECJ) are also pointed to by Michael Bothe, 'The Decision of the Italian Constitutional Court Concerning the Jurisdictional Immunities of Germany', Italian Yearbook of International Law 24 (2015), 25-36.

${ }^{19}$ Since the FCC generally acknowledges the primacy of EU law, it would demand even more compelling reasons for disobedience here. From a different angle, Alessandro Bufalini, chapter 'Waiting for Negotiations', in this volume, points out that compared to supranational law, disobeying international law might have an even more dangerous impact given the fragility of a legal system with only limited institutions for law enforcement. While this certainly carries some conviction, the present state of the EU seems not as robust as one might wish for, looking particularly at the rise of illiberalism and authoritarian policies in central and eastern Europe: see, eg, Jacques Rupnik, 'Surging Illiberalism in the East', Journal of Democracy 27 (2016), 77-87; R Daniel Kelemen, 'Europe's Authoritarian Equilibrium: Invoking Article 7 Against Poland Won't Be Enough', Foreign Affairs (22 December 2017), available at https://www.foreignaffairs.com/ articles/hungary/2017-12-22/europes-authoritarian-equilibrium.

${ }^{20} \mathrm{Cf}$ FCC, European Arrest Warrant II, (n 14), 361-364, citing the extensive jurisprudence of the European Court of Human Rights concerning trials in absentia.

${ }^{21}$ For a closer analysis, see Thomas Jäger/Alexander Höse/Kai Oppermann (eds), Deutsche Außenpolitik (Wiesbaden: Springer VS $2^{\text {nd }}$ ed 2011); Philip Liste, Völkerrecht-Sprechen: Die Konstruktion demokratischer Völkerrechtspolitik in den USA und der Bundesrepublik Deutschland (Baden-Baden: Nomos 2012); Michael Staack, 'Die Außenpolitik der Bundesrepublik Deutschland', in Michael Staack (ed), Einführung in die Internationale Politik. Studienbuch (Munich: Oldenbourg $5^{\text {th }}$ ed 2012), 213-261.

${ }^{22}$ In parenthesis, it might be mentioned that Italy is faced with a comparable situation concerning its stand towards the functional immunity of state officials in the Enrica Lexie case; cf Douglas Guilfoyle, 'Shooting fishermen mistaken for pirates: Jurisdiction, immunity and State responsibility', EJIL Talk!, (2 March 2012), available at www.ejiltalk.org/shooting-fishermen-mistaken-forpirates-jurisdiction-immunity-and-state-responsibility/; Hari Sankar, 'Jurisdictional and Immunity Issues in the Story of Enrica Lexie: A Case of Shoot \& Scoot turns around!', EJIL Talk!, (25 March 2013), available at www.ejiltalk.org/jurisdictional-and-immunity-issues-in-the-story-of-enricalexie-a-case-of-shoot-scoot-turns-around/.
} 
reasons, Germany tries to keep its history out of foreign courtrooms. That the Federal Government, when declaring acceptance of the ICJ's compulsory jurisdiction according to Article 36(2) of the Statute in 2008, included the-admittedly widely used-limitation to 'disputes arising after the present declaration' does not therefore come as a surprise.

It would be a misrepresentation to see this as an unwillingness to bear responsibility for atrocities committed by Germans during the Nazi period. At a political level, Germany is generally prepared to accept that responsibility, not only symbolically but financially also. ${ }^{23}$ From 1956 to the end of 2013, Germany paid a total of $€ 71$ billion in reparations to surviving victims of National Socialism (NS). ${ }^{24}$ However, the patchwork of instruments set up soon after the foundation of the Federal Republic of Germany (which understood itself — contrary to the German Democratic Republic - as successor to the German Reich, and thus accepted legal responsibility) was very much characterized by selectivity. ${ }^{25}$ Lobbyists, pressure groups, or a lack thereof, and the rise of the Cold War left their mark on the outcome. ${ }^{26}$ The central element of the diverse set of reparation instruments, the Federal Compensation Act (Bundesentschädigungsgesetz) of 1956 and amended in 1965, excluded foreign NS victims (with a later exception for Jewish emigrants from eastern Europe). Their reparation was primarily left to the interstate level. Individual titles to reparation could be introduced by way of national legislation, but only if the Federal legislator chose to do so. This position has been upheld in recent years by the FCC when dealing with—eventually unsuccessful—claims of former forced labourers and war crime victims. $^{27}$

\footnotetext{
${ }^{23} \mathrm{Cf}$ the assessments by Dinah Shelton, Remedies in International Human Rights Law (Oxford: OUP $3^{\text {rd }}$ ed 2015), 181; Ariel Colonomos/Andrea Armstrong, 'German Reparations to the Jews after World War II: A Turning Point in the History of Reparations', in Pablo de Greiff (ed), The Handbook of Reparations (Oxford: OUP 2006), 391-417, at 411.

${ }^{24}$ Joachim Käppner, 'Summe der Schande', Süddeutsche Zeitung (17 March 2015); Christoph Schult, 'Stunde der Bewährung', Der Spiegel Geschichte 2 (2015), 120-123. For a detailed overview on all relevant compensatory measures, see Bericht der Bundesregierung über Wiedergutmachung und Entschädigung für nationalsozialistisches Unrecht sowie über die Lage der Sinti, Roma und verwandter Gruppen, Deutscher Bundestag, Drucksache 10/6287 (31 October 1986) and Federal Ministry of Finance, Compensation for National Socialist Injustice: Indemnification Provisions, May 2019, available at https://www.bundesfinanzministerium.de/Content/EN/ Standardartikel/Press_Room/Publications/Brochures/2018-08-15-entschaedigung-ns-unrecht-engl. html.

${ }^{25}$ For a closer analysis, see Andreas von Arnauld, 'Damages for the Infringement of Human Rights in Germany', in Ewa Bagińska (ed), Damages for Violations of Human Rights: A Comparative Study of Domestic Legal Systems (Berlin/Heidelberg/New York: Springer 2015), 101-135, at 121-124. See also Riccardo Pavoni, chapter 'A Plea for Legal Peace', and Francesco Francioni, chapter 'Overcoming the Judicial Conundrum', in this volume.

${ }^{26}$ Walter Schwarz, 'Das Recht der Wiedergutmachung und seine Geschichte', Juristische Schulung 26 (1986), 433-440; Hans Günter Hockerts, 'Wiedergutmachung in Deutschland: Eine historische Bilanz 1945-2000', Vierteljahrshefte für Zeitgeschichte 49 (2001), 167-214.

${ }^{27}$ Bundesverfassungsgericht, Decision of 13 May 1996, 2 BvL 33/93, BVerfGE 94, 315 (Forced Labourers); Chamber Decision of 28 June 2004, 2 BvR 1379/01, Neue Juristische Wochenschrift
} 
While this jurisprudence conforms well to the traditional and still prevailing view in public international law, ${ }^{28}$ reparation at the interstate level has had its flaws, too. ${ }^{29}$ In order to support the Federal Republic of Germany in its political and economic recovery, its western partners agreed in Article 5(2) of the London Agreement on German External Debts to defer the '[c]onsideration of claims arising out of the second World War by countries which were at war with or were occupied by Germany during that war, and by nationals of such countries, against the Reich and agencies of the Reich (...) until the final settlement of the problem of reparation'. ${ }^{30}$ This clause was widely understood as a moratorium on claims against Germany until the conclusion of a peace treaty. ${ }^{31}$ However, only some of the states that could have claimed reparation were represented in the negotiations. ${ }^{32}$

During the 1960s, Germany concluded lump sum agreements on reparations with 11 western European countries, among them Italy. Payments to Italian citizens who were subjected to NS persecution were covered by a bilateral treaty of 2 June $1961^{33}$ on the basis of which Germany paid at that time DM (Deutsche Mark) 40 million to

(2004), 3257; Chamber Decision of 15 February 2006, 2 BvR 1476/03, Neue Juristische Wochenschrift (2006), 2542, at 2543; Albrecht Randelzhofer/Oliver Dörr, Entschädigung für Zwangsarbeit? Zum Problem individueller Entschädigungsansprüche von ausländischen Zwangsarbeitern während des Zweiten Weltkrieges gegen die Bundesrepublik Deutschland (Berlin: Duncker \& Humblot 1994); Hugo J Hahn, 'Individualansprüche auf Wiedergutmachung von Zwangsarbeit im Zweiten Weltkrieg: Das Entschädigungsgesetz vom 2.8.2000', Neue Juristische Wochenschrift 53 (2000), 3521-3526.

${ }^{28} \mathrm{Cf}$, even for present-day violations of international humanitarian law, Emanuela-Chiara Gillard, 'Reparation for violations of international humanitarian law', International Review of the Red Cross 85 (2003), 529-554; Roland Bank, 'Is There a Substantive Right to Compensation for Individual Victims of Armed Conflicts against a State under International Law?', German Yearbook of International Law 49 (2006), 367-412; Philipp Stöckle, 'Victims Caught Between a Rock and a Hard Place: Individual Compensation Claims against Troop-Contributing States', Die FriedensWarte/Journal of International Peace and Organization 88 (2013), 119-141; Christian Tomuschat, 'State Responsibility and the Individual Right to Compensation Before National Courts', in Andrew Clapham/Paolo Gaeta (eds), Oxford Handbook of International Law in Armed Conflict (Oxford: OUP 2014), 811-839; Emily L Camins, 'Needs or Rights? Exploring the Limitations of Individual Reparations for Violations of International Humanitarian Law', International Journal of Transitional Justice 10 (2016), 126-145.

${ }^{29}$ Helmut Rumpf, 'Die deutsche Frage und die Reparationen', Heidelberg Journal of International Law 33 (1973), 344-371, at 354-355; Hans Günter Hockerts, 'Wiedergutmachung in Deutschland 1945-1990: Ein Überblick', Aus Politik und Zeitgeschichte 63(25/26) (2013), 15-20.

${ }^{30}$ Agreement on German External Debts, 27 February 1953, UNTC No 4764 (London Debt Agreement).

${ }^{31}$ That peace treaty never came into being. Functionally, the Treaty on the Final Settlement with Respect to Germany, 12 September 1990, 1696 UNTS 115 (Two-plus-Four Treaty), which paved the way for German reunification, is widely regarded as the equivalent of such a treaty.

${ }^{32}$ Though Italy was among the signatories of the London Agreement, the negotiations were mostly conducted by the Tripartite Commission on German Debts, ie France, the UK, and the US.

${ }^{33}$ Agreement between the Federal Republic of Germany and Italy on the Compensation for Italian Nationals Subjected to National-Socialist Measures of Persecution (Bonn, 2 June 1961), German and Italian version published in Bundesgesetzblatt II 5 July 1963 No 22, 791. 
Italy. It has been the position of the German government until today that this treaty was meant to cover all individual claims, even though hundreds of thousands ${ }^{34}$ of IMIs and other victims of German wartime action were by definition excluded from the notion of 'persecution'. ${ }^{35}$ Without going into detail, given the wide-reaching mediatisation of the individual in international law in 1961, it would be reasonable to argue that with this treaty both states agreed to limit the circle of beneficiaries, for whose suffering Italy would demand and receive compensation from Germany, to those groups covered by the 1961 treaty. It has to be borne in mind that in Article 77 (4) of the 1947 Peace Treaty with the Allied Powers, ${ }^{36}$ Italy -also on behalf of its citizens - had already waived all potential rights to compensation against Germany concerning 'claims for loss or damage arising during the war'. In another bilateral treaty of 2 June 1961, the so-called Globalabkommen, Italy agreed vis-à-vis the Federal Republic of Germany to waive all claims related to the period between 1 September 1939 and 8 May 1945 (Article 2) - against payment of a further DM40 million. ${ }^{37}$ On the surface, the situation seems settled between Germany and Italy.

\section{Unsettling Settlements: Growing Discontent}

Yet, over the last 15-20 years, there has been a growing discontent with this final settlement, or Schlussstrich approach, for three reasons. Firstly, there are the inherent limitations of the 1961 treaty that excluded IMIs from the notion of 'victim'. Though their treatment might not formally have been in violation of the laws applicable in the 1940s, their fate at least prompted — or even necessitated — a change to these laws in the 1949 Geneva Conventions: for example, Article 4A(3) of the Third Geneva Convention, in granting prisoner-of-war status for 'Members of regular armed forces who profess allegiance to a government or an authority not recognized by the

\footnotetext{
${ }^{34}$ While the exact number is not undisputed, most independent sources estimate that there were around 600,000 IMIs forced to work in Germany. See, eg, Bob Moore, 'Enforced Diaspora: The Fate of Italian Prisoners of War during the Second World War?', War in History 22 (2015), 174-190, at 184; and Deutsch-Italienische Historikerkommission, 'Bericht der von den Außenministern der Bundesrepublik Deutschland und der Italienischen Republik am 28.3.2009 eingesetzten Deutsch-Italienischen Historikerkommission', (July 2012), available at www. villavigoni.it/contents/files/Abschlussbericht.pdf, 1-180, at 33.

${ }^{35}$ Art 1(1) limits compensation to those 'persecuted on grounds of race, religion, or ideology' ('aus Gründen der Rasse, des Glaubens oder der Weltanschaung'/'per ragione di razza, fede o ideologia '). Arguably, one might view the IMIs as covered by persecution for ideological reasons; this, however, was presumably not how that clause was understood by the parties in 1961 or later. ${ }^{36}$ Treaty of Peace with Italy, 10 February 1947, 49 UNTS 3.

${ }^{37}$ Agreement between the Federal Republic of Germany and Italy on the Settlement of Certain Property-Related, Economic and Financial Questions (Bonn, 2 June 1961), German and Italian version published in Bundesgesetzblatt II 26 June 1963, 668.
} 
Detaining Power', was explicitly meant to address the situation of IMIs. ${ }^{38}$ So there is a strong moral claim by those victims to be included in any given compensation scheme, even though, legally, the principles of non-retroactivity of international legal obligations and of mediatisation of the individual through its national state prove to be gatekeepers to the sphere of law.

Secondly, there is a change to international law. The last 25 years have witnessed a shift in perspective: the formerly state-centred system has gradually opened up to include the individual and their rights. As a parallel development, the traditional concept of interstate responsibility has come under pressure to recognize the right of individuals to reparation for human rights violations. This has found expression in the 'Basic Principles and Guidelines on the Right to a Remedy and Reparation for Victims of Gross Violations of International Human Rights Law and Serious Violations of International Humanitarian Law', adopted by the UN General Assembly in December 2005. ${ }^{39}$ Claims for reparation do not only concern recent cases of human rights violations; on numerous occasions there have been attempts to redress historical injustices by way of compensation claims filed with national and international courts alike. ${ }^{40}$

This leads to the third reason for growing discontent. While, again, the principles of intertemporal law and the arguably 'soft' character of the UN Principles of 2005 shield Germany from claims based on international law, Germany has in some cases agreed to set up compensation schemes - though only for certain groups of victims, mostly due to political pressure. Before 1990, it had been only the Jewish Claims Conference, backed by Israel and the US, that had managed as early as 1952 to secure payments from the Federal Republic of Germany. After 1990, the victims of forced and slave labour in German companies during WWII managed to get their claims accepted. In order to avert the impending threat of judicial proceedings in the US, the Federal Government together with German trade and industry associations set up the Foundation 'Remembrance, Responsibility and Future' (Erinnerung, Verantwortung und Zukunft), with a funding figure of DM10 billion. ${ }^{41}$ However,

\footnotetext{
${ }^{38}$ For the historical background, see Jean de Preux et al, III Geneva Convention Relative to the Treatment of Prisoners of War: Commentary (Jean Pictet ed, Geneva: ICRC 1960), 61-64. Cf also Article 50 of the same Convention limiting the kind of work prisoners of war might be compelled to do by the detaining power.

${ }^{39}$ UN General Assembly, A/Res/60/147, 16 December 2005. See Theo van Boven, 'Victim's Right to a Remedy and Reparation: The New United Nations Principles and Guidelines', in Carla Ferstman/Mariana Goetz/Alan Stephens (eds), Reparations for Victims of Genocide, War Crimes and Crimes against Humanity: Systems in Place and Systems in the Making (Leiden: Nijhoff 2009), 19-40; José Brunner/Constantin Goschler/Norbert Frei, 'Die Globalisierung der Wiedergutmachung', Aus Politik und Zeitgeschichte (17 June 2013), 23-30.

${ }^{40}$ Shelton, Remedies 2015 (n 23), 263-278.

${ }^{41}$ Roland Bank, 'New Programs for Payments to Victims of National Socialist Injustice', German Yearbook of International Law 44 (2003), 307-352; Bardo Fassbender, 'Compensation for Forced Labour in WWII: The German Compensation Law of 2 August 2000', Journal of International Criminal Justice 3 (2005), 243-252. See also Riccardo Pavoni, chapter 'A Plea for Legal Peace', Stefan Kadelbach, chapter 'State Immunity, Individual Compensation for Victims of Human Rights
} 
on the basis of a controversial distinction, Italian forced labourers were by and large excluded from that scheme. Keeping this in mind, it must have come as another setback that in 2015 Germany agreed to a voluntary payment to surviving former Soviet prisoners of war. ${ }^{42}$ Though only symbolic in amount (a mere $€ 2,500$ per victim), this at least signals a willingness on Germany's part to accept responsibility and to recognize the recipient as a victim. Such a recognition was belatedly extended in 2016 to IMIs - in the form of a memorial site and an exhibition sponsored by the German government. ${ }^{43}$ Without wanting to criticize these well-designed and thoughtful mementos, other than their fellow sufferers, the IMIs still remain outside any financial compensation scheme, and crucially they have not been included in the process of deciding on the most adequate way to address the historical wrongs they experienced.

\section{Unmaking History: Possible Solutions}

In an answer to a parliamentary question, the German Federal Government stated in March 2016 that Italy remains obliged to observe the ICJ judgment of February 2012 and that it does not intend at the moment to institute further proceedings against Italy, while nonetheless reserving the right to do so. ${ }^{44}$ In substance, the German government repeated its position that, as far as Italian citizens are concerned, all matters of compensation had been dealt with comprehensively in the 1961 Treaties. Legally speaking, this position is sound. Sometimes, however, relying on law-or a certain legal framing of a problem-misses one of the law's central objectives: to settle disputes. Behind the legal concepts of state immunity, ius cogens, mediatisation, and intertemporality lies a yet unresolved conflict: that of the WWII victims 'in oblivion'. The IMIs and others that suffered from German wartime action have been doubly denied recognition as victims: diachronically, in that their suffering has been treated as lawful under the rules applicable during WWII while it would be illegal today under the amended Geneva rules-the injustices of non-retroactivity; synchronically, by excluding them from the notion of 'victims' in the 1961 treaty; and again, by not offering them a compensation scheme, which was done, for example, for other forced labourers and the former Soviet prisoners of war-the injustices of differentiation. While formally applied correctly, the rule of

\footnotetext{
Crimes, and Future Prospects', and Filippo Fontanelli, chapter 'Sketches for a Reparation Scheme', in this volume.

${ }^{42} \mathrm{Cf}$ Richtlinie über eine Anerkennungsleistung an ehemalige sowjetische Kriegsgefangene, 30 September 2015, Bundesanzeiger AT 14.10.2015 B1. Cf also Jörg Luther, chapter "A Story of "Trials and Errors" that Might Have No Happy End' and Giovanni Boggero/Karin Oellers-Frahm, chapter 'Between Cynicism and Idealism', in this volume.

${ }^{43}$ See, inter alia, Oellers-Frahm, 'A Never-Ending Story' 2016 (n 8), 202.

${ }^{44}$ Deutscher Bundestag, Drucksache 18/7852, 10 March 2016. See also Drucksache 18/3492, 9 December 2014.
} 
non-retroactivity of law(s) turns out to be too one-dimensional for legally assessing the historical past. While it certainly has a reasonable moral basis in cases of criminal accountability (namely, the principle nulla poena sine lege praevia), in cases of state responsibility it is unable to grasp that when raising historical claims, the claimants do not mean history but the present. They are not arguing for correcting a historic record for historiography's sake. The question is how today's law accommodates the needs of those who still suffer from historic legal discrimination-or even legal annihilation. Once these exclusionary rules have been overcome, they should no longer determine the legal position of those who suffered from them.

I do not intend to argue for the opening of Pandora's box by allowing individual claims for compensation based on historical wrongdoings. There are inherent dangers in such a concept. Judges are not historians; they are, to quote Robert Cover, 'people of violence' whose decrees on historical truth might turn out even more exclusionary and difficult to revise than historical narratives outside the courtroom. ${ }^{45}$ What is more, adjudicating history might prove bottomless once one goes further back, with claims relating to early colonialism and beyond. However, in most of the recent cases of 'history taken to court,' compensation is but a secondary aim, the primary aim being to make the voice of the victims heard, allowing space for them to 'tell their own story' as a counter-narrative to the hegemonic discourse of the former oppressors. ${ }^{46}$ Courts are turned into fora to make one's story heard-and this process is used as leverage to exert pressure on the political system to listen.

If the law is to solve conflicts and serve justice, it should provide means to address this need. Elsewhere, and in the context of German colonial history, I have suggested an obligatio de negotiando following from the breach of fundamental ethical principles of law in force already at the time of the original violation. ${ }^{47}$ In our case, this could be the Martens clause, with its appeal to the 'laws of humanity and the dictates of public conscience'. ${ }^{48}$ The treatment of 'military internees', the killing of members of resistance movements and of hostages has surely shaken the public conscience, paving the way for the amendments to the Geneva Conventions in

\footnotetext{
${ }^{45}$ Robert Cover, 'Nomos and Narrative', Harvard Law Review 97 (1983-1984), 4-68, at 53. David J Bederman, 'Foreign Office International Legal History', in Matthew Craven/Malgosia Fitzmaurice/ Maria Vogiatzi (eds), Time, History and International Law (Leiden: Brill 2007), 43-64, at 62-63, reminds us of the 'enduring truth', 'that legal history and legal truth are not always the same thing, and they certainly cannot be ascertained by the same means and modalities'.

${ }^{46} \mathrm{Cf}$ generally Richard Delgado, 'Storytelling for Oppositionists and Others', Michigan Law Review 87 (1989), 2411-2441; Milner S Ball, 'Stories of Origin and Constitutional Possibilities', Michigan Law Review 87 (1989), 2280-2319; Peter Fitzpatrick, The Mythology of Modern Law (London/New York: Routledge 1992); Andreas von Arnauld, 'Norms and Narrative', German Law Journal 18 (2017), 309-329, at 317-320.

${ }^{47}$ von Arnauld, 'Damages for Infringement' 2015 (n 25), 128.

${ }^{48}$ Hague Convention (IV) Respecting the Laws and Customs of War on Land, 18 October 1907, Preamble, para 8.
} 
$1949^{49}$ - a prime example of Durkheim's colère publique in action. ${ }^{50}$ Arguably, even if not formally violating specific provisions of the law of warfare in force at the time $^{51}$ (different from other atrocities committed by Germans during WWII), the treatment of IMIs at least constituted a violation of fundamental ethical principles incorporated through the Martens clause into the sphere of legal obligations. From these 'soft' obligations one might derive not a strict obligation to compensate but a procedural obligation to engage in negotiations as a means of satisfaction. These negotiations are open-ended, that is, they might not necessarily lead to financial compensation, but could also lead to setting up a commemorative scheme like the one introduced in 2016. This, however, should not be decided over the heads of the victims themselves.

If one takes this approach seriously, the victims have to be included in these negotiations, especially since Italy in 1947 and 1961 was prepared to waive their interests. ${ }^{52}$ That, generally, violations of humanitarian law and principles do not give rise to individual claims for reparation could be disregarded once the responsible state decides to lift the veil of mediatisation for some groups of victims by setting up reparation programmes for individual claimants (the above-mentioned 'injustice of differentiation'). That we are dealing with past wrongs and injustices does not alter the fact that the decision (not) to enter into serious talks about the most adequate form of compensation is to be taken in the present. This decision has to conform to today's moral and legal standards. ${ }^{53}$ Non-retroactivity of the law is one of those standards (standards of present-day justice, that is). However, that its undifferentiated use might undermine the law's capability of solving present-day

\footnotetext{
${ }^{49}$ See n 38 .

${ }^{50}$ Emile Durkheim, De la division du travail: Etude sur l'organisations des sociétés supérieures (Paris: Felix Alcan 1893), 109-112. On Durkheim's influence on the concept of solidarity in international law in the writings of Georges Scelle, see Andreas Fischer-Lescano, 'Global Constitutional Struggles: Human Rights between colère publique and colère politique', in Wolfgang Kaleck/Michael Ratner/Tobias Singelnstein/Peter Weiss (eds), International Prosecution of Human Rights Crimes (Berlin/Heidelberg/New York: Springer 2007), 13-27, at 24-27.

${ }^{51} \mathrm{Cf}$ de Preux, III Geneva Convention 1960 (n 38), 264-265, as to the different views of the belligerents under the 1929 Geneva Conventions.

${ }^{52}$ For a similar reason, Krajewski/Singer, 'Should Judges be Front-Runners?' 2012 (n 3), 31-33, argue de lege ferenda for an inclusion of victims in proceedings before the ICJ in cases of human rights abuses in order to include 'the missing voices'.

${ }^{53} \mathrm{Cf}$, mutatis mutandis, the-lesser known and received—second principle of intertemporal law as stated by Max Huber, in the Island of Palmas (Netherlands v US), Award of 4 April 1928, 2 UN Rep Intl Arb Awards, 829-871, at 845: 'As regards the question which of different legal systems prevailing at successive periods to be applied in a particular case (the so-called intertemporal law), a distinction must be made between the creation of rights and the existence of rights. The same principle which subjects the act creative of a right to the law in force at the time the right arises, demands that the existence of the right, in other words its continued manifestation, shall follow the conditions required by the evolution of law.' For a closer analysis, see Ulf Linderfalk, 'The Application of International Legal Norms Over Time: The Second Branch of Intertemporal Law', Netherlands International Law Review 58 (2011), 147-172.
} 
disputes, which_like practically all disputes_are rooted in the past, has hopefully been made plausible in this chapter.

Is Germany then legally obliged to open negotiations? Certainly not on the basis of a traditional reading of international and constitutional law. If one is prepared, however, to accept the idea of procedural rights and obligations following from violations of 'ethical-legal' norms and how they are being addressed today, Germany is, in fact and in law, obliged to offer serious talks to victims. For its participation in the historical wrongs - at this late point, merely mentioning Mussolini's Repubblica di Salò will have to suffice-and for its waiver of rights of Italian citizens, Italy ought to be included in the negotiations and in any compensation scheme. ${ }^{54}$ In following this path, the law would better live up to its claim of settling conflicts by addressing injustices.

\section{References}

Arnauld, Andreas von, 'Damages for the Infringement of Human Rights in Germany', in Ewa Bagińska (ed), Damages for Violations of Human Rights: A Comparative Study of Domestic Legal Systems (Berlin/Heidelberg/New York: Springer 2015), 101-135

Arnauld, Andreas von, 'Norms and Narrative', German Law Journal 18 (2017), 309-329

Ball, Milner S, 'Stories of Origin and Constitutional Possibilities', Michigan Law Review 87 (1989), 2280-2319

Bank, Roland, 'Is There a Substantive Right to Compensation for Individual Victims of Armed Conflicts against a State under International Law?', German Yearbook of International Law 49 (2006), 367-412

Bank, Roland, 'New Programs for Payments to Victims of National Socialist Injustice', German Yearbook of International Law 44 (2003), 307-352

Bederman, David J, 'Foreign Office International Legal History', in Matthew Craven/Malgosia Fitzmaurice/Maria Vogiatzi (eds), Time, History and International Law (Leiden: Brill 2007), 43-64

Bilz, Christopher, 'Konfrontation statt Kooperation? "Solange III" und die Melloni-Entscheidung des EuGH', Juwiss Blog, (15 March 2016), available at www.juwiss.de/26-2016/

Bothe, Michael, 'Remedies of Victims of War Crimes and Crimes against Humanities: Some Critical Remarks on the ICJ's Judgment on the Jurisdictional Immunity of States', in Anne Peters/Evelyne Lagrange/Stefan Oeter/Christian Tomuschat (eds), Immunities in the Age of Global Constitutionalism (Leiden: Brill 2015), 99-115

Bothe, Michael, 'The Decision of the Italian Constitutional Court Concerning the Jurisdictional Immunities of Germany', Italian Yearbook of International Law 24 (2015), 25-36

Boven, Theo van, 'Victim's Right to a Remedy and Reparation: The New United Nations Principles and Guidelines', in Carla Ferstman/Mariana Goetz/Alan Stephens (eds), Reparations for Victims of Genocide, War Crimes and Crimes against Humanity: Systems in Place and Systems in the Making (Leiden: Nijhoff 2009), 19-40

Brunner, José/Constantin Goschler/Norbert Frei, 'Die Globalisierung der Wiedergutmachung', Aus Politik und Zeitgeschichte (17 June 2013), 23-30

\footnotetext{
${ }^{54}$ See also Filippo Fontanelli, chapter 'Sketches for a Reparation Scheme', and Francesco Francioni, chapter 'Overcoming the Judicial Conundrum', in this volume.
} 
Calisto, Marco, 'Jurisdictional Immunities of the State: Germany v Italy before the ICJ from an Italian Perspective', German Yearbook of International Law 55 (2012), 319-343

Camins, Emily L, 'Needs or Rights? Exploring the Limitations of Individual Reparations for Violations of International Humanitarian Law', International Journal of Transitional Justice 10 (2016), 126-145

Cannizzaro, Enzo, 'Jurisdictional Immunities and Judicial Protection: The Decision of the Italian Constitutional Court No. 238 of 2014', Rivista di diritto internazionale 98 (2015), 126-134

Cataldi, Giuseppe, 'A Historic Decision of the Italian Constitutional Court on the Balance Between the Italian Legal Order's Fundamental Values and Customary International Law', Italian Yearbook of International Law 24 (2015), 37-52

Colonomos, Ariel/Andrea Armstrong, 'German Reparations to the Jews after World War II: A Turning Point in the History of Reparations', in Pablo de Greiff (ed), The Handbook of Reparations (Oxford: OUP 2006), 391-417

Cover, Robert, 'Nomos and Narrative', Harvard Law Review 97 (1983-1984), 4-68

Delgado, Richard, 'Storytelling for Oppositionists and Others', Michigan Law Review 87 (1989), 2411-2441

Durkheim, Emile, De la division du travail: Etude sur l'organisations des sociétés supérieures (Paris: Felix Alcan 1893)

Esposito, Carlos, 'Jus Cogens and Jurisdictional Immunities of States at the International Court of Justice: “A Conflict Does Exist”, Italian Yearbook of International Law 21 (2011), 161-174

Fassbender, Bardo, 'Compensation for Forced Labour in WWII: The German Compensation Law of 2 August 2000', Journal of International Criminal Justice 3 (2005), 243-252

Fischer-Lescano, Andreas, 'Global Constitutional Struggles: Human Rights between colère publique and colère politique', in Wolfgang Kaleck/Michael Ratner/Tobias Singelnstein/Peter Weiss (eds), International Prosecution of Human Rights Crimes (Berlin/Heidelberg/New York: Springer 2007), 13-27

Fitzpatrick, Peter, The Mythology of Modern Law (London/New York: Routledge 1992)

Fontanelli, Filippo, 'I know it's wrong but I just can't do right: First impressions on judgment no. 238 of 2014 of the Italian Constitutional Court', VerfBlog, (27 October 2014), available at https://verfassungsblog.de/know-wrong-just-cant-right-first-impressions-judgment-238-2014italian-constitutional-court/

Francioni, Francesco, 'Access to Justice and Its Pitfalls: Reparation for War Crimes and the Italian Constitutional Court', Journal of International Criminal Justice 14 (2016), 629-636

Francioni, Francesco, 'From Utopia to Disenchantment: The Ill Fate of "Moderate Monism" in the ICJ Judgment on The Jurisdictional Immunities of the State', European Journal of International Law 23 (2012), 1125-1132

Gillard, Emanuela-Chiara, 'Reparation for violations of international humanitarian law', International Review of the Red Cross 85 (2003), 529-554

Guilfoyle, Douglas, 'Shooting fishermen mistaken for pirates: Jurisdiction, immunity and State responsibility', EJIL Talk!, (2 March 2012), available at www.ejiltalk.org/shooting-fishermenmistaken-for-pirates-jurisdiction-immunity-and-state-responsibility/

Hahn, Hugo J, 'Individualansprüche auf Wiedergutmachung von Zwangsarbeit im Zweiten Weltkrieg: Das Entschädigungsgesetz vom 2.8.2000', Neue Juristische Wochenschrift 53 (2000), 3521-3526

Hockerts, Hans Günter, 'Wiedergutmachung in Deutschland 1945-1990: Ein Überblick', Aus Politik und Zeitgeschichte 63(25/26) (2013), 15-20

Hockerts, Hans Günter, 'Wiedergutmachung in Deutschland: Eine historische Bilanz 1945-2000', Vierteljahrshefte für Zeitgeschichte 49 (2001), 167-214

Iovane, Massimo, 'The Italian Constitutional Court Judgment No. 238 and the Myth of the "Constitutionalization" of International Law', Journal of International Criminal Justice 14 (2016), 595-605

Jäger, Thomas/Alexander Höse/Kai Oppermann (eds), Deutsche Außenpolitik (Wiesbaden: Springer VS $2^{\text {nd }}$ ed 2011) 
Käppner, Joachim, 'Summe der Schande', Süddeutsche Zeitung (17 March 2015)

Kelemen, R Daniel, 'Europe's Authoritarian Equilibrium: Invoking Article 7 Against Poland Won't Be Enough', Foreign Affairs (22 December 2017), available at https://www.foreignaffairs.com/ articles/hungary/2017-12-22/europes-authoritarian-equilibrium

Kolb, Robert, 'The Relationship between the International and the Municipal Legal Order: Reflections on the Decision no 238/2014 of the Italian Constitutional Court', Questions of International Law: Zoom Out 2 (2014), 5-16

Krajewski, Markus/Christopher Singer, 'Should Judges be Front-Runners? The ICJ, State Immunity and the Protection of Fundamental Human Rights', Max Planck Yearbook of United Nations Law 16 (2012), 1-34

Kunz, Raffaela, 'The Italian Constitutional Court and "Constructive Contestation": A Miscarried Attempt?', Journal of International Criminal Justice 14 (2016), 621-627

Linderfalk, Ulf, 'The Application of International Legal Norms Over Time: The Second Branch of Intertemporal Law', Netherlands International Law Review 58 (2011), 147-172

Liste, Philip, Völkerrecht-Sprechen: Die Konstruktion demokratischer Völkerrechtspolitik in den USA und der Bundesrepublik Deutschland (Baden-Baden: Nomos 2012)

Moore, Bob, 'Enforced Diaspora: The Fate of Italian Prisoners of War during the Second World War?', War in History 22 (2015), 174-190

Oellers-Frahm, Karin, 'A Never-Ending Story: The International Court of Justice-The Italian Constitutional Court-Italian Tribunals and the Question of Immunity', Heidelberg Journal of International Law 76 (2016), 193-202

Oellers-Frahm, Karin, 'Das italienische Verfassungsgericht und das Völkerrecht-eine unerfreuliche Beziehung', Europäische Grundrechte-Zeitschrift 42 (2015), 8-16

Palchetti, Paolo, 'Can State Action on Behalf of Victims Be an Alternative to Individual Access to Justice in Case of Grave Breaches of Human Rights?', Italian Yearbook of International Law 24 (2015), 53-60

Palombella, Gianluigi, 'German War Crimes and the Rule of International Law', Journal of International Criminal Justice 14 (2016), 607-613

Peters, Anne, 'Let Not Triepel Triumph-How To Make the Best Out of Sentenza No. 238 of the Italian Constitutional Court for a Global Legal Order', EJIL Talk!, (22 December 2014), available at www.ejiltalk.org/let-not-triepel-triumph-how-to-make-the-best-out-of-sentenzano-238-of-the-italian-constitutional-court-for-a-global-legal-order-part-i/

Pisillo Mazzeschi, Riccardo, 'Access to Justice in Constitutional and International Law: The Recent Judgment of the Italian Constitutional Court', Italian Yearbook of International Law 24 (2015), 9-23

Preux, Jean de et al, III Geneva Convention Relative to the Treatment of Prisoners of War: Commentary (Jean Pictet ed, Geneva: ICRC 1960)

Randelzhofer, Albrecht/Oliver Dörr, Entschädigung für Zwangsarbeit? Zum Problem individueller Entschädigungsansprüche von ausländischen Zwangsarbeitern während des Zweiten Weltkrieges gegen die Bundesrepublik Deutschland (Berlin: Duncker \& Humblot 1994)

Rumpf, Helmut, 'Die deutsche Frage und die Reparationen', Heidelberg Journal of International Law 33 (1973), 344-371

Rupnik, Jacques, 'Surging Illiberalism in the East', Journal of Democracy 27 (2016), 77-87

Sankar, Hari, 'Jurisdictional and Immunity Issues in the Story of Enrica Lexie: A Case of Shoot \& Scoot turns around!', EJIL Talk!, (25 March 2013), available at www.ejiltalk.org/jurisdictionaland-immunity-issues-in-the-story-of-enrica-lexie-a-case-of-shoot-scoot-turns-around/

Schult, Christoph, 'Stunde der Bewährung', Der Spiegel Geschichte 2 (2015), 120-123

Schwarz, Walter, 'Das Recht der Wiedergutmachung und seine Geschichte', Juristische Schulung 26 (1986), 433-440

Shah, Sangeeta, 'Jurisdictional Immunities of the State: Germany v Italy', Human Rights Law Review 12 (2012), 555-573

Shelton, Dinah, Remedies in International Human Rights Law (Oxford: OUP $3^{\text {rd }}$ ed 2015) 
Staack, Michael, 'Die Außenpolitik der Bundesrepublik Deutschland', in Michael Staack (ed), Einführung in die Internationale Politik. Studienbuch (Munich: Oldenbourg $5^{\text {th }}$ ed 2012), 213-261

Stöckle, Philipp, 'Victims Caught Between a Rock and a Hard Place: Individual Compensation Claims against Troop-Contributing States', Die Friedens-Warte/Journal of International Peace and Organization 88 (2013), 119-141

Tomuschat, Christian, 'State Responsibility and the Individual Right to Compensation Before National Courts', in Andrew Clapham/Paolo Gaeta (eds), Oxford Handbook of International Law in Armed Conflict (Oxford: OUP 2014), 811-839

Trapp, Kimberley/Alex Mills, 'Smooth Runs the Water where the Brook is Deep: The Obscured Complexities of Germany v Italy', Cambridge Journal of International and Comparative Law 1 (2012), 153-168

Wuerth, Ingrid, 'International Law in Domestic Courts and the Jurisdictional Immunities of the State Case', Melbourne Journal of International Law 13 (2012), 819-837

Würkert, Felix, 'Historische Immunität?', Archiv des Völkerrechts 53 (2015), 90-120

Open Access This chapter is licensed under the terms of the Creative Commons Attribution 4.0 International License (http://creativecommons.org/licenses/by/4.0/), which permits use, sharing, adaptation, distribution and reproduction in any medium or format, as long as you give appropriate credit to the original author(s) and the source, provide a link to the Creative Commons license and indicate if changes were made.

The images or other third party material in this chapter are included in the chapter's Creative Commons license, unless indicated otherwise in a credit line to the material. If material is not included in the chapter's Creative Commons license and your intended use is not permitted by statutory regulation or exceeds the permitted use, you will need to obtain permission directly from the copyright holder. 